\title{
Pesquisa de Staphylococcus aureus em Amostras de Queijo Minas Artesanal
}

\author{
Bruna Lamim de Souza (I), Emília Maricato Pedro dos Santos (I), \\ Edilene Bolutari Baptista (I), Carolina dos Santos Fernandes da \\ Silva (I)
}

(I) UNIPAC - Universidade Presidente Antônio Carlos (Av. Juiz de Fora, 1100 - Bairro Granjas Bethânia - Juiz de Fora, MG.)

\section{Resumo}

O queijo Minas é um alimento que há muito tempo vem sendo consumido pelas famílias brasileiras, sendo um derivado lácteo de suma importância na pirâmide alimentar, com alto teor de proteína, lipídios, carboidratos, minerais, como cálcio, fósforo, e vitaminas. O queijo Minas artesanal é feito a partir do leite cru, o que aumenta o risco de proliferação de microorganismos patogênicos. Dessa forma, requer muitos cuidados para que não ocorram contaminações que coloquem em risco a saúde humana. $\mathrm{O}$ objetivo do presente trabalho foi analisar a qualidade, as condições higiênico-sanitárias e a possível contaminação por Staphylococcus aureus em queijos Minas artesanais recém-fabricados e ao longo do prazo de validade, pela técnica de contagem direta em placas e confirmação por provas bioquímicas. Foram adquiridas 16 amostras de queijo Minas artesanal (sem registro em órgão de inspeção de produtos de origem animal) comercializadas em diferentes pontos de venda em Juiz de Fora, MG. Essas amostras foram analisadas no $1^{\circ}, 7^{\circ}$ e $14^{\circ}$ dia após a aquisição das mesmas. Durante este período de experimentação, as amostras ficaram acondicionadas em sacos plásticos estéreis e sob refrigeração $\left(4^{\circ} \mathrm{C}\right) . \mathrm{O}$ isolamento e contagem do micro-organismo foram realizados em ágar Baird-Parker adicionado de telurito e gema de ovo, utilizando-se as diluições 10-1. 10-2 e 10-3, em duplicata. Para a confirmação do microorganismo, as seguintes provas bioquímicas seriam realizadas: coloração de

\footnotetext{
Referência:

Bruna Lamim de Souza (I), Emília Maricato Pedro dos Santos (I), Edilene Bolutari Baptista (I), Carolina dos Santos Fernandes da Silva (I).Pesquisa de Staphylococcus Aureus em Amostras de Queijo Minas Artesanal. In: Anais do 12을 Congresso Latinoamericano de Microbiologia e Higiene de Alimentos - MICROAL 2014 [= Blucher Food Science Proceedings, num.1, vol.1]. São Paulo: Editora Blucher, 2014. DOI 10.5151/foodsci-microal-192
} 
Gram, teste de catalase, teste de coagulase em tubo, teste da DNAse, teste da endonuclease e teste de Voges-Proskauer. Os resultados obtidos demostraram que $100 \%$ das amostras estavam dentro dos padrões estabelecidos para a presença de Staphylococcus aureus em queijos $(<5,0 \mathrm{x}$ 102UFC.g-1), uma vez que não houve crescimento de micro-organismos em nenhuma das amostras estudadas. Geralmente, é esperado que ocorra a presença desse tipo de micro-organismo em queijos, principalmente os artesanais, visto que são fabricados com leite cru e são bastante manipulados, porém não isso não foi observado na presente pesquisa. $\mathrm{A}$ partir destes resultados pode-se concluir que a qualidade microbiológica das amostras estudadas apresentou-se satisfatória, não oferecendo riscos a saúde do consumidor.A avaliação da qualidade dos queijos Minas artesanais vendidos no comércio de Juiz de Fora-MG atestou que as amostras atendiam aos requisitos mínimos previstos pela legislação brasileira. Foi verificada boa qualidade na higiene, manipulação, conservação dos queijos e qualidade da matéria prima utilizada na fabricação dos mesmos. Deve-se considerar, porém, que somente a análise para verificar a presença de Staphylococcus aureus não garante que o produto esteja livre de qualquer outra contaminação.E, ainda, pode-se considerar a possibilidade da presença de inibidores em tais amostras, os quais podem não ter permitido o crescimento dos micro-organismos pesquisados.

Palavras-Chave: Derivados lácteos, Microbiologia, Segurança alimentar Agência de Fomento: 